\title{
Self-compacting concrete with limestone powder for transport infrastructure
}

\section{Самоуплотняющийся бетон с карбонатным наполнителем для объектов транспортной инфраструктуры}

\author{
L.O Larsen, \\ V.V. Naruts, \\ National Research Moscow State Civil Engineering \\ University, Moscow, Russia
}

\author{
Канд. техн. наук, доцент О.А. Ларсен, \\ аспирант В.В. Наруть, \\ Национальный исследовательский Московский \\ государственный строительный \\ университет, г. Москва, Россия
}
Ключевые слова: самоуплотняющийся бетон карбонатный наполнитель; энергосбережение; гражданское строительство; конструкции; прочность; водонепроницаемость; морозостойкость

Key words: self-compacting concrete; limestone powder; energy efficiency; strength; buildings; construction; civil engineering; water permeability frost resistance

Abstract. At the beginning of $X X I$ century in civil engineering and buildings of transport infrastructure, such as tunnels, elements of bridges, viaducts and roads, it is more expedient to use conventionally vibrated concretes which have almost universally replaced prefabricated constructions. However, in objects with high congested reinforcement or in cases where vibration is impossible it is more preferable to apply self-compacting concrete (SSC) mixtures. SCC possesses the ability to take form shape without any mechanical aid. The most important requirement for SCC is high flowability without the segregation of aggregate during placement. Despite the low water-cement ratio of the fresh self-compacting concrete mixture the bleeding is still possible. That is why fillers such as natural pozzolana, calcined clay (metakaolin), silica fume, fly-ash, slag, and quarry dusts should be used. Furthermore, mineral admixtures can improve energy efficiency and particle packing, decrease cost and permeability of self-compacting concrete. In this study, the properties of SCC with limestone powder as partial replacement of Portland cement was established by applying mathematical experiment planning method. The obtained SCC gave high early compressive strength within 3 days in the range of $41.3 \mathrm{MPa}$ while its 28 day strength ranged of $69.0 \mathrm{MPa}$. The result of this study indicated the possibility of adding limestone powder in SCC with optimum percentage content around $38 \%$. The researched SCC had density of hardened and fresh concrete mix in the ranges of $2438 \mathrm{~kg} / \mathrm{m} 3$ and $2452 \mathrm{~kg} / \mathrm{m} 3$ respectively. The investigated SCC concrete with limestone powder showed high rate of water permeability in the range of $1.6 \mathrm{MPa}(\mathrm{W} 16)$ and high frost resistance in the ranges of F2400. It can be explained by additive's high water retention capacity and increase of hydration degree and, as a consequence, decrease of capillary porosity. That is why the developed SCC with limestone powder has high compressive strength and excellent durability performance.

Аннотация. На объектах гражданского строительства и транспортной инфраструктуры в конструкциях, имеющих высокий коэффициент армирования, и в случаях, когда вибрирование бетонных смесей осуществить не представляется возможным, необходимо применение эффрективных самоуплотняющихся бетонных смесей, которые получили широкое распространение в последние десятилетия В мировой практике. В работе представлены результате экспериментальных исследований при разработке состава самоуплотняющегося бетона для объектов транспортной инфраструктуры с использованием наполнителей на основе отходов дробления карбонатных пород. Для оптимизации состава применялся трехфакторный метод математического планирования эксперимента, композиционный план на кубе типа В3, обеспечивающий максимальную прочность при достижении требуемых технологических показателей. Установлено, что введение эффрективного разжижжителя в виде гиперпластификатора, значительно снижает водосодержание бетонной смеси, что предотвращает расслаиваемость самоуплотняющегося бетона и повышает эксплуатационные свойства: прочность, морозостойкость, водонепроницаемость. Экспериментально установлено, что увеличение содержания карбонатного наполнителя ведёт к повышению прочности только до определённого предела, оптимальная дозировка которого, соответствующая максимальной 
прочности, составляет 0.38 от массы цемента. Карбонатный микронаполнитель, обладая высокой водоудерживающей способностью, повышает степень гидратации цемента, способствует уменьшению капиллярной и общей пористости, тем самым влияя на показатели прочности. Получен самоуплотняющийся бетон со средней плотностью 2438 кг/м3, прочностью на сжатие 69 МПа, морозостойкостью F2400 и водонепроницаемостью W16.

\section{Introduction}

At the beginning of XXI century in constructions, such as tunnels, elements of bridges, viaducts and roads conventionally vibrated concretes are widely used. However, it is more preferable to apply selfcompacting concrete mixtures in structures with high density reinforcement or in cases where vibration is impossible [1]. Due to high rate of flowability self-compacting concrete takes form shape and passes through the bars without any vibration. Self-compacting concrete has several advantages such as technological benefits, environmental impact and energy efficiency [2].

The difference in concrete mix design between SCC and conventionally vibrated concrete is in lower coarse aggregate content, increased paste content, low water/powder ratio, increased superplasticiser [3]. The required level of flowability (slump more than $600 \mathrm{~mm}$ ) can be achieved by adding polycarboxylate-based admixtures with maintaining of technological properties such as workability retention at the period of setting time into the formwork [4, 5]. Despite low water-cement ratio bleeding of the mix is still possible.

The high cost of SCC resulted from the high cement content is the main factor impeding the widespread of SCC use. Since cement is the most expensive component of concrete, its reducing content is an economical solution. The cost of SCC can be decreased incorporating various supplementary cementitious materials such as natural pozzolana [6], calcined clay (metakaolin) [7], silica fume, fly-ash [8], slag [9] and quarry dusts [10]. The mineral admixtures can improve particle packing and decrease the permeability of concrete. Therefore, the durability of concrete is also increased.

Besides the economical benefits, the use of recycled waste materials in concrete could reduce environmental pollution and carbon dioxide emission. Large volumes of these powders are accumulated and it is a big problem to propose utilization of these by-products from the aspects of disposal and health hazards [11].

In addition supplementary cementitious materials do not only decrease the cost of self-compacting concrete [12], but also improve flowability [13] and durability [14], reduce the heat of hydration in massive structures [15], increase early strength and control bleeding [16].

Calcium carbonate based mineral fillers are widely used and can give excellent rheological properties and a good finish. Limestone powder is a by-product collected from the quarrying process of carbonate rocks. In Russia, 2014, more than 300 million tons of natural limestone were extracted and recycled to produce 209 million tons of lime coarse aggregate and 10 million tons of lime binders [17, 18]. The main component of limestone powder is calcium carbonate. It does not possess pozzolanic activity [19], but its use in SCC improves the deformability and viscosity, as well as reduction porosity [20]. Partial replacement of cement by limestone filler brings the enhancement in fluidity and a reduction of the yield stress [21].

The amount of limestone powder in cementitious materials can vary from 10 to $50 \%$ [22]. Due to positive influence on the properties of SCC and economic benefits the limestone powder is a major component of many SCC mixtures [23]. Some research has been conducted regarding the properties of limestone powder in self-compacting concrete in recent years. However, most of the previous studies are limited or contain compositions with different quantity of the filler. The aim of this study is to establish the optimum quantity of limestone powder in SCC and its influence on technological and performance properties.

\section{Materials, methods and mixture proportioning}

\section{Cement}

The cement used in this study was Ordinary Portland Cement type CEM I $42.5 \mathrm{~N}$ Holcim Rus in accordance with [24]. Mineral content was: $\mathrm{C}_{3} \mathrm{~A}=7.2 \%, \mathrm{C}_{3} \mathrm{~S}=60.8 \%, \mathrm{C}_{2} \mathrm{~S}=13.7 \%, \mathrm{C}_{4} \mathrm{AF}=10.0 \%$ with specific surface area equal to $3600 \mathrm{~cm}^{2} / \mathrm{g}$. Chemical composition is presented in Table 1 .

Ларсен О.А., Наруть В.В. Самоуплотняющийся бетон с карбонатным наполнителем для объектов транспортной инфраструктуры // Инженерно-строительный журнал. 2016. № 8(68). С. 76-85. 
Table 1. Chemical composition of CEM $42.5 \mathrm{~N}$

\begin{tabular}{|c|c|c|c|}
\hline Component & Percentage & Component & Percentage \\
\hline $\mathrm{SiO}_{2}$ & 18.6 & $\mathrm{TiO}_{2}$ & 0.3 \\
\hline $\mathrm{Al}_{2} \mathrm{O}_{3}$ & 4.5 & $\mathrm{P}_{2} \mathrm{O}_{5}$ & 0.1 \\
\hline $\mathrm{CaO}$ & 63.6 & $\mathrm{SO}_{3}$ & 3.1 \\
\hline $\mathrm{Fe}_{2} \mathrm{O}_{3}$ & 3.1 & $\mathrm{Na}_{2} \mathrm{O}$ & 0.2 \\
\hline $\mathrm{MgO}$ & 3.2 & $\mathrm{~K}_{2} \mathrm{O}$ & 0.6 \\
\hline
\end{tabular}

\section{Mineral filler}

The limestone powder was sourced from limestone quarry Saltykovskoe field, grinded in laboratory mill to a specific surface area equal to $3500 \mathrm{~cm}^{2} / \mathrm{g}$. Chemical composition of limestone powder is presented in Table 2.

Table 2. Chemical composition of limestone powder

\begin{tabular}{|c|c|c|c|c|c|c|}
\hline Component & \multicolumn{7}{|c|}{ Percentage, \% } \\
\hline \multirow{2}{*}{ Limestone powder } & $\mathrm{SiO}_{2}$ & $\mathrm{Al}_{2} \mathrm{O}_{3}$ & $\mathrm{Fe}_{2} \mathrm{O}_{3}$ & $\mathrm{CaO}$ & $\mathrm{MgO}$ & Loss on ignition \\
\cline { 2 - 7 } & 0.79 & 0.45 & 0.72 & 54.94 & 0.48 & 42.62 \\
\hline
\end{tabular}

\section{Aggregates}

Crushed granite with a maximum size of $20 \mathrm{~mm}$ according to [25], specific gravity of $2.68 \mathrm{~kg} / \mathrm{m}^{3}$ and water absorption of $0.2 \%$ according to [26] was used as coarse aggregate. Quartz sand was used as fine aggregate with specific gravity equal to $2.63 \mathrm{~kg} / \mathrm{m}^{3}$ with the fineness modulus of 1.2 . The particle size distributions of both sand and crushed granite, obtained by sieving, are shown in Figures 1 and 2 .

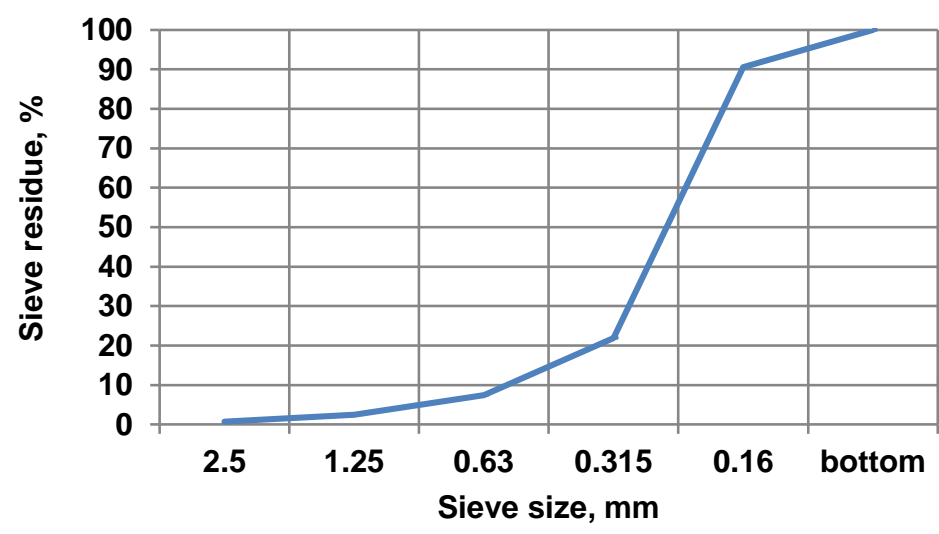

Fig. 1. Grading of fine aggregate

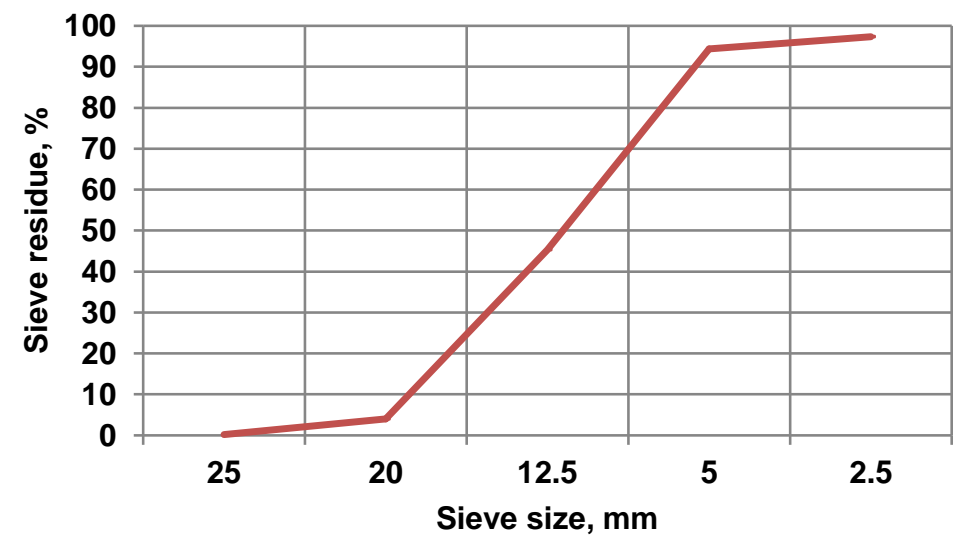

Fig. 2. Grading of coarse aggregate

Larsen L.O., Naruts V.V. Self-compacting concrete with limestone powder for transport infrastructure. Magazine of Civil Engineering. 2016. No. 8. Pp. 76-85. doi: 10.5862/MCE.68.8 


\section{Chemical admixture}

To adjust the workability of concrete mixture, maintain its dispersing effect during the time, required for transport and application, a superplasticizer based on polycarboxylate ethers Sika ViscoCrete 5-800 was used in accordance with [27, 28].

\section{Evaluation of self-compactability}

At the beginning of the experiment preliminary composition of self-compacting concrete with the following characteristics presented in Table 3 was developed. It was experimentally determined that the dosage of superplasticizer using slump-flow test on the paste [29] until the rheological parameters attained satisfactory level $(660-750 \mathrm{~mm})$. Necessary correlation between limestone powder, coarse aggregate and fine aggregate is based on requirements of self-compactability [30] and terms of concrete mixtures pumpability [31].

Trial batches of SCC with simultaneous adjustment were produced. The weights of constituent materials for producing one cubic meter of SCC mixtures, calculated using the absolute volume method.

Table 3. Preliminary compositions of the mixture

\begin{tabular}{|c|c|}
\hline Material & Unit mass $\left(\mathrm{kg} / \mathrm{m}^{3}\right)$ \\
\hline CEM I $42.5 \mathrm{~N}$ & 480 \\
\hline Limestone powder & 190 \\
\hline Quartz sand & 720 \\
\hline Crushed granite & 765 \\
\hline Water & 170 \\
\hline PCE SP Sika ViscoCrete 5-800 & 5.8 \\
\hline
\end{tabular}

\section{Mathematical planning method}

The obtained SCC composition was corrected by using three-factor mathematical planning method. A compositional plan for a $B_{3}$-type cube was adopted for the implementation of the experiment. The factors of variation were: quantity of Portland Cement in $\mathrm{kg} / \mathrm{m}^{3}$; quantity of limestone powder in \% by weight of Portland Cement; quantity of chemical admixture Sika ViscoCrete 5-800 in \% by weight of Portland Cement. Other parameters remained unchanged. The zero level of variation was adopted for the preliminary composition.

\section{Evaluation of hardened properties}

The cube samples $100 \times 100 \times 100 \mathrm{~mm}$ were cased in accordance with [32, 33, 34] from each composition with no compaction. Demolding of the cubes was carried out 24 hours after casting. The cubes were placed in a $20^{\circ} \mathrm{C}$ water curing tank until tests. The compressive strength of each cube was measured according to [35] at the age of 28 days.

\section{Frost resistance and water permeability}

Frost resistance was determined in accordance with [36] by third accelerated method (freezing and thawing in $5 \%$ aqueous solution of $\mathrm{NaCl}$, temperature of freezing was $-50^{\circ} \mathrm{C}$ ) on cube samples $100 \times 100 \times 100 \mathrm{~mm}$ at the age of 28 days by placing samples in a $20^{\circ} \mathrm{C}$ water curing tank. Water permeability was determined by "wet spot" method following [37] at the age of 28 days.

\section{Results and Discussion \\ Optimization of the compressive strength of SCC}

The levels of variation factors are shown in Table 4. The results of the compressive strength at 28 days are shown in Table 5.

Ларсен О.А., Наруть В.В. Самоуплотняющийся бетон с карбонатным наполнителем для объектов транспортной инфраструктуры // Инженерно-строительный журнал. 2016. № 8(68). С. 76-85. 
Table 4. Levels and intervals varying factors

\begin{tabular}{|c|c|c|c|c|c|c|}
\hline \multicolumn{3}{|c|}{ Factor } & \multirow{2}{*}{\multicolumn{3}{|c|}{$\begin{array}{l}\text { Levels varying } \\
\text { factors }\end{array}$}} & \multirow{3}{*}{$\begin{array}{l}\text { Intervals varying } \\
\text { factors }\end{array}$} \\
\hline \multirow[t]{2}{*}{ Parameter } & \multicolumn{2}{|c|}{ Description } & & & & \\
\hline & Natural & Code & +1 & 0 & -1 & \\
\hline $\begin{array}{c}\text { Quantity of } \\
\text { CEM I } 42.5 \mathrm{~N}, \\
\mathrm{~kg} / \mathrm{m}^{3}\end{array}$ & $X_{1}$ & $x_{1}$ & 570 & 480 & 390 & 90 \\
\hline $\begin{array}{c}\text { Quantity of } \\
\text { Limestone } \\
\text { powder, mass } \\
\text { proportion of PC }\end{array}$ & $X_{2}$ & $x_{2}$ & 0.5 & 0.4 & 0.3 & 0.1 \\
\hline $\begin{array}{c}\text { Quantity of PCE } \\
\text { SP Sika } \\
\text { ViscoCrete 5-800, } \\
\% \text { of PC }\end{array}$ & $X_{3}$ & $x_{3}$ & 1.4 & 1.2 & 1 & 1 \\
\hline
\end{tabular}

Table 5. Matrix of the system response

\begin{tabular}{|c|c|c|c|c|c|c|c|}
\hline \multirow[b]{2}{*}{ No } & \multirow{2}{*}{$\begin{array}{c}\text { CEM I } 42.5 \mathrm{~N}, \\
\mathrm{~kg} / \mathrm{m}^{3}\end{array}$} & \multirow{2}{*}{$\begin{array}{l}\text { Limestone } \\
\text { powder, in } \\
\text { proportion } \\
\text { of PC }\end{array}$} & \multirow{2}{*}{$\begin{array}{c}\text { PCE SP } \\
\text { Sika } \\
\text { ViscoCrete } \\
5-800 \text {, in \% } \\
\text { of PC }\end{array}$} & \multicolumn{3}{|c|}{ Coded factor } & \multirow{2}{*}{$\begin{array}{c}\text { Parameter of } \\
\text { optimization } \\
\begin{array}{c}\text { Compressive } \\
\text { strength in age } \\
\text { of } 28 \text { days } \\
(\mathrm{MPa})\end{array} \\
\end{array}$} \\
\hline & & & & $\mathbf{x}_{1}$ & $\mathrm{X}_{2}$ & $\mathbf{X}_{3}$ & \\
\hline 1 & 2 & 3 & 4 & 5 & 6 & 7 & 8 \\
\hline 1 & 390 & 0.3 & 1 & -1 & -1 & -1 & 47.6 \\
\hline 2 & 570 & 0.3 & 1 & 1 & -1 & -1 & 61.3 \\
\hline 3 & 390 & 0.5 & 1 & -1 & 1 & -1 & 50.2 \\
\hline 4 & 570 & 0.5 & 1 & 1 & 1 & -1 & 67.7 \\
\hline 5 & 390 & 0.3 & 1.4 & -1 & -1 & 1 & 44.3 \\
\hline 6 & 570 & 0.3 & 1.4 & 1 & -1 & 1 & 52.2 \\
\hline 7 & 390 & 0.5 & 1.4 & -1 & 1 & 1 & 49.9 \\
\hline 8 & 570 & 0.5 & 1.4 & 1 & 1 & 1 & 68.0 \\
\hline 9 & 390 & 0.4 & 1.2 & -1 & 0 & 0 & 53.4 \\
\hline 10 & 570 & 0.4 & 1.2 & 1 & 0 & 0 & 65.3 \\
\hline 11 & 480 & 0.3 & 1.2 & 0 & -1 & 0 & 47.7 \\
\hline 12 & 480 & 0.5 & 1.2 & 0 & 1 & 0 & 49.6 \\
\hline 13 & 480 & 0.4 & 1 & 0 & 0 & -1 & 48.6 \\
\hline 14 & 480 & 0.4 & 1.4 & 0 & 0 & 1 & 54.1 \\
\hline
\end{tabular}

The number of experiments was 14 , the number of repeated experiments was 3 . The preparation of the concrete mixtures was performed in a laboratory mixer. The final mixing time after dosage of all materials was 90 seconds.

The final purpose of the data processing was to obtain the equation of regression by the number of defined characteristics with significant coefficients for the selected variables:

$$
y=52.06+6.98 x_{1}+3.32 x_{2}+7.3 x_{1}^{2}-3.4 x_{2}^{2}+0.93 x_{1} x_{2}+0.83 x_{2} x_{3}
$$

The analysis of regression equations was carried by a mathematical method. Graphic dependences are presented in Figures 3 and 4. 


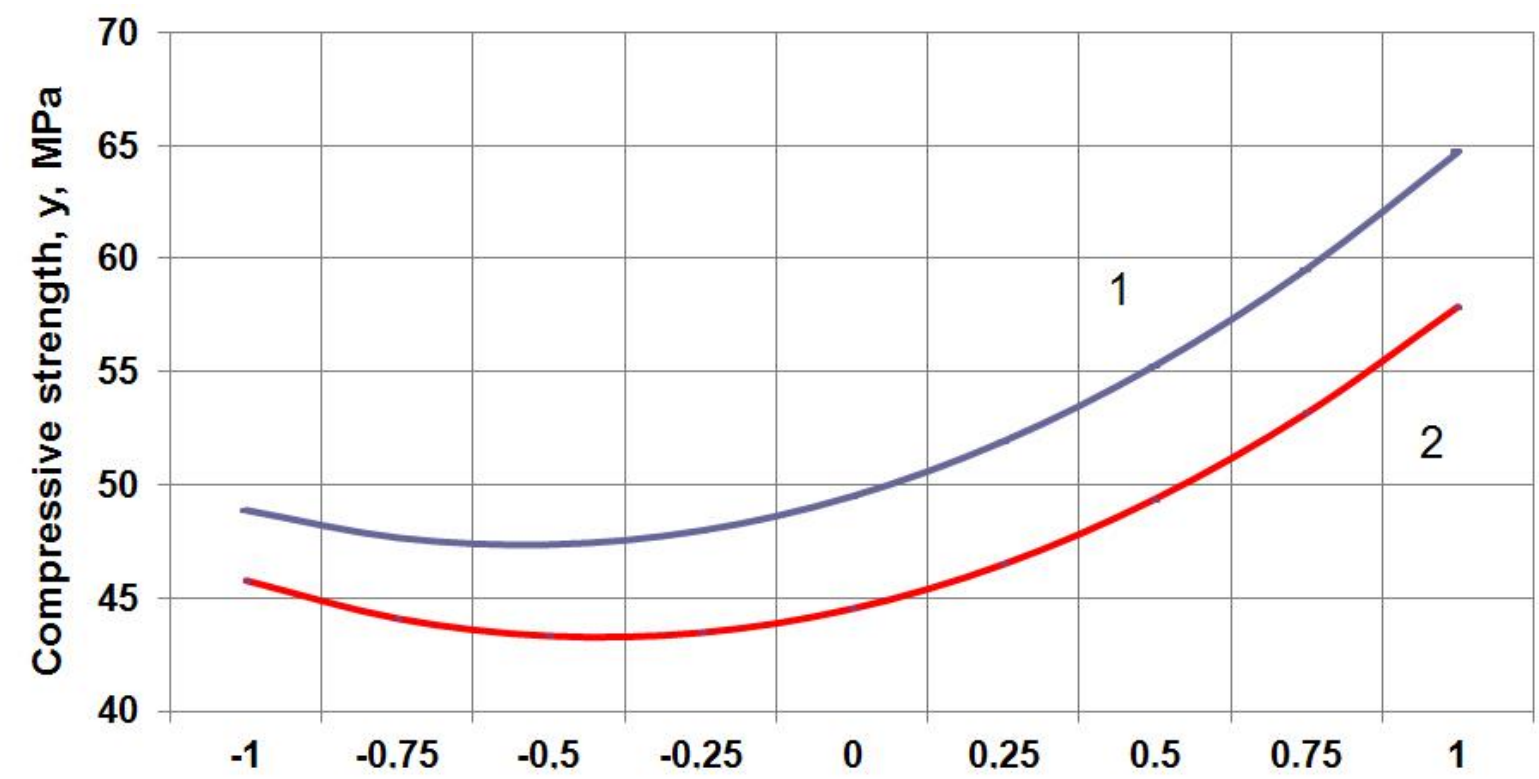

Figure 3. Dependency graphs of $y=f(C E M I 42.5 \mathrm{~N})$ :

1 - dependency graph of $y=f(C E M I 42.5 N)$ if $x_{2}=1, x_{3}=1$;

2 - dependency graph of $y=f(C E M I 42.5 N)$ if $x_{2}=-1, x_{3}=1$

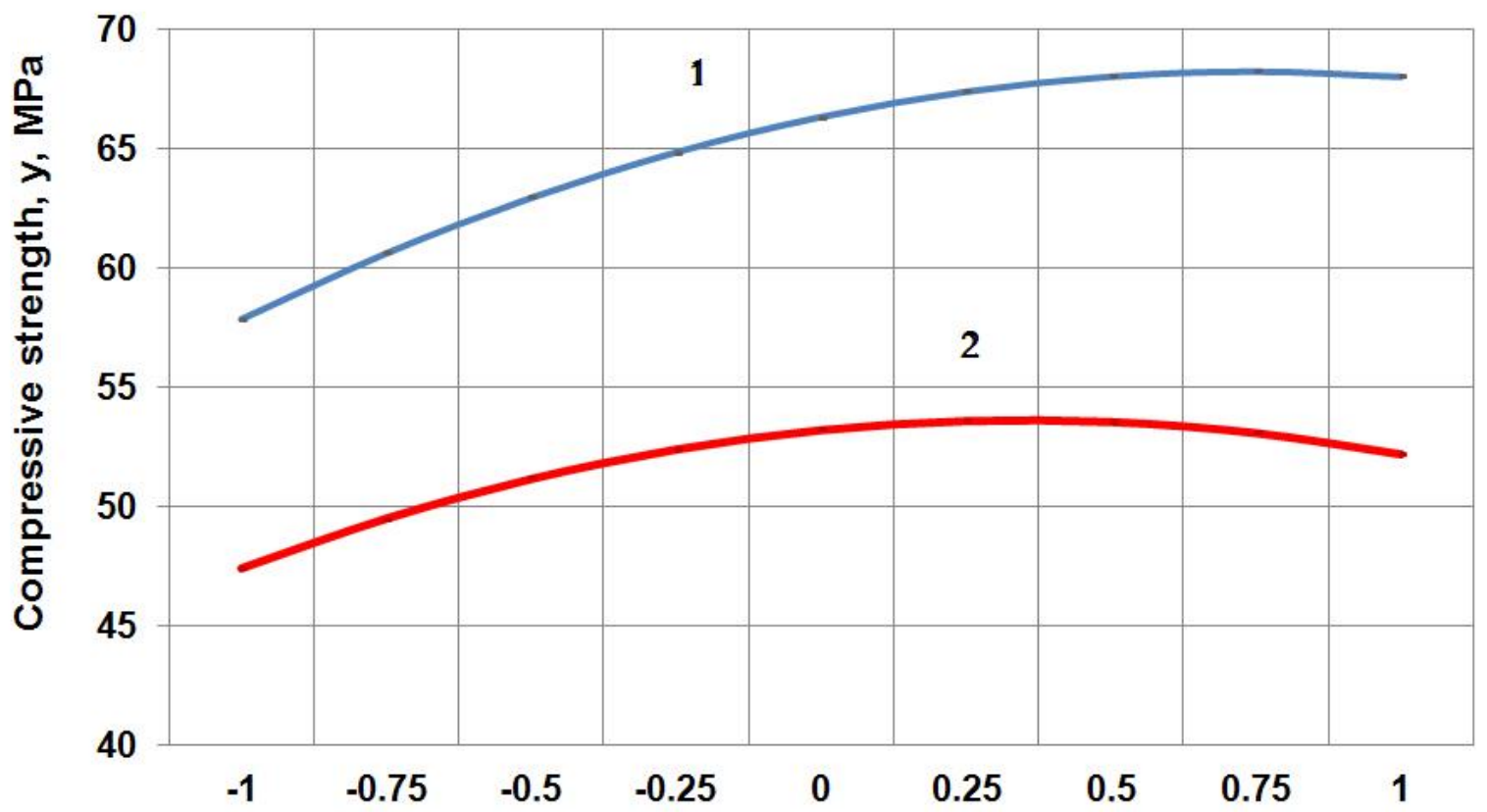

Figure 4. Dependency graphs of $y=f$ (limestone powder):

1 - dependency graph of $y=f$ (limestone powder) if $x_{1}=1, x_{3}=1$;

2 - dependency graph of $y=f$ (limestone powder) if $x_{1}=-1, x_{3}=1$

The composition with the highest compressive strength and optimum dosages of variable components was selected. The consumption of materials for one cubic meter based on the equation of regression (1) is presented in Table 6. 
Table 6. Content of concrete mix by using mathematical planning method

\begin{tabular}{|c|c|c|c|c|c|c|c|c|}
\hline \multicolumn{6}{|c|}{$\begin{array}{c}\text { Weights of the materials for one cubic meter of the } \\
\text { concrete mixture (kg) }\end{array}$} & \multirow[b]{2}{*}{$\begin{array}{c}\text { Estimated } \\
\text { density } \\
\left(\mathbf{k g} / \mathbf{m}^{3}\right)\end{array}$} & \multirow{2}{*}{ 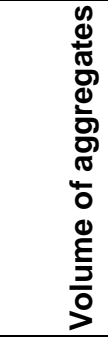 } & \multirow[b]{2}{*}{$\begin{array}{l}\text { Estimated } \\
\text { compressive } \\
\text { strength } \\
\text { (MPa) }\end{array}$} \\
\hline 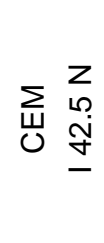 & 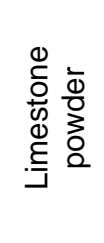 & 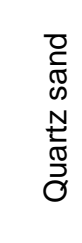 & 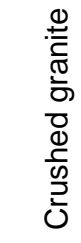 & $\begin{array}{l}\text { के } \\
\text { Uू } \\
\text { 口. }\end{array}$ & $\begin{array}{l}\frac{\bar{\phi}}{\pi} \\
\frac{\pi}{3}\end{array}$ & & & \\
\hline 570 & 217 & 720 & 765 & 8 & 190 & 2462 & 0.56 & 68.24 \\
\hline
\end{tabular}

Table 7. Properties of fresh concrete mixtures and hardened concrete

\begin{tabular}{|c|c|c|c|c|c|c|c|c|}
\hline \multirow[t]{2}{*}{$\begin{array}{l}\text { Density } \\
\left(\mathrm{kg} / \mathrm{m}^{3}\right)\end{array}$} & \multirow{2}{*}{$\begin{array}{l}\text { Slump } \\
\text { flow } \\
\text { (mm) }\end{array}$} & \multirow{2}{*}{$\begin{array}{l}t_{500} \\
(s)\end{array}$} & \multirow{2}{*}{$\begin{array}{c}\text { Density of } \\
\text { hardened } \\
\text { concrete } \\
\left(\mathrm{kg} / \mathrm{m}^{3}\right)\end{array}$} & \multicolumn{4}{|c|}{$\begin{array}{c}\text { Compressive strength } \\
(\mathrm{MPa})\end{array}$} & \multirow{2}{*}{$\begin{array}{l}\text { Deviation from } \\
\text { calculated strength, \% }\end{array}$} \\
\hline & & & & 3 & 7 & 14 & 28 & \\
\hline 2452 & 690 & 9 & 2438 & 41.3 & 56.5 & 59.3 & 69.0 & +1.11 \\
\hline
\end{tabular}

As it seen from the Table 6 and 7 the content of limestone powder in optimal SCC was $38 \%$ by weight of Portland cement.

\section{Frost resistance and water permeability}

Table 8. Frost resistance and water permeability of self-compacting concrete

\begin{tabular}{|c|c|c|c|c|c|}
\hline $\begin{array}{c}\text { Testing } \\
\text { method }\end{array}$ & $\begin{array}{c}\text { The number of } \\
\text { cycles of freezing/ } \\
\text { thawing without } \\
\text { failure and weight } \\
\text { loss }\end{array}$ & $\begin{array}{c}\text { Grade of freezing/ } \\
\text { thawing }\end{array}$ & $\begin{array}{c}\text { Sample size of } \\
\text { cylinders }(\mathbf{m m})\end{array}$ & $\begin{array}{c}\text { Water permeability } \\
\text { (MPa) }\end{array}$ & $\begin{array}{c}\text { Grade of } \\
\text { water } \\
\text { permeabilit } \\
\text { y }\end{array}$ \\
\hline $\begin{array}{c}\text { Third } \\
\text { rapid }\end{array}$ & 55 & $\mathrm{~F}_{2} 400$ & $\begin{array}{c}\mathrm{d}=150 \mathrm{~mm} \\
\mathrm{~h}=150 \mathrm{~mm}\end{array}$ & 1.6 & $\mathrm{~W} 16$ \\
\hline
\end{tabular}

\section{Conclusion}

The test results showed possibility of using limestone powder in SCC. The results demonstrate positive influence of limestone powder on technological and performance properties. The obtained composition was optimized by mathematical planning method. It was determined that the optimal dosage of limestone powder in the developed SCC is $38 \%$ to achieve technological requirements $(690 \mathrm{~mm}$ of slump flow) with cement consumption equal to $570 \mathrm{~kg} / \mathrm{m}^{3}$. It was established that the adding of limestone powder in amount of $38 \%$ together with the superplasticizer causes increasement of compressive strength in 3, 7, 14 and 28-day in the range of 41.3,56.5, 59.3 and 69.0 MPa respectively that correlates with compressive strength of existing SCC with other fillers [38]. The introduction of limestone powder provides high density of concrete $\left(2438 \mathrm{~kg} / \mathrm{m}^{3}\right)$ that exceed existing results [39] and could enhance corrosion resistance and high durability. The developed SCC demonstrated 55 cycles of freezing/thawing, low rate of water permeability in the range of $1.6 \mathrm{MPa}$ that can be explained by high water retention capacity on increase of the hydration degree by creating a high dense homogenous structure of the concrete.

\section{References}

1. Barragán B., Gettu R., Pintado X., Bravo M. Design of high strength self-compacting concrete for tunnel linings. Measuring, Monitoring and Modeling Concrete Properties. An International Symposium dedicated to Professor Surendra P. Shah. Northwestern University, USA, 2006. Pp. 485-491.

2. Mueller F.V., Wallevik O.H., Khayat K.H. A new homogeneity assessment concept applied to evaluate selfconsolidation and segregation stability of self-consolidating concrete. Proceedings pro100: 8th International RILEM Symposium on Self-Compacting Concrete - SCC. 2016.

\section{Литература}

1. Barragán B., Gettu R., Pintado X., Bravo M. Design of high strength self-compacting concrete for tunnel linings. Measuring, Monitoring and Modeling Concrete Properties // An International Symposium dedicated to Professor Surendra P. Shah. Northwestern University, USA, 2006. Pp. 485-491.

2. Mueller F.V., Wallevik O.H., Khayat K.H. A new homogeneity assessment concept applied to evaluate selfconsolidation and segregation stability of self-consolidating concrete // Proceedings pro100: 8th International RILEM Symposium on Self-Compacting Concrete - SCC. 2016.

Larsen L.O., Naruts V.V. Self-compacting concrete with limestone powder for transport infrastructure. Magazine of Civil Engineering. 2016. No. 8. Pp. 76-85. doi: 10.5862/MCE.68.8 
Pp. 123-132.

3. Ramanathan P., Baskar I., Muthupriya P., Venkatasubramani R. Performance of self-compacting concrete containing different mineral admixtures. Journal of Civil Engineering. 2013. Vol. 17. No. 2. Pp. 465-472.

4. Muellera F.V., Wallevika O.H., Khayat K.H. Linking solid particle packing of Eco-SCC to material performance. Cement and Concrete Composites. 2014. Vol. 54. Pp. 117125.

5. Abbas S., Nehdi M.L., Saleem M. A. Ultra-High Performance Concrete: Mechanical Performance, Durability, Sustainability and Implementation Challenges. International Journal of Concrete Structures and Materials. 2016. Vol. 10. No. 3. Pp. 271-295.

6. Adekunle S., Ahmad S., Maslehuddin M., Al-Gahtani H. J. Properties of SCC prepared using natural pozzolana and industrial wastes as mineral fillers. Cement and Concrete Composites. 2015. Vol. 62. Pp. 125-133.

7. Dinakar P., Sahoo P.K., Sriram G. Effect of metakaolin content on the properties of high strength concrete. International Journal of Concrete Structures and Materials. 2013. Vol. 7. No. 3. Pp. 215-223.

8. Da Silva P.R., De Brito J. Durability performance of selfcompacting concrete (SCC) with binary and ternary mixes of fly ash and limestone filler. Materials and Structures. 2016. Vol. 49. No. 7. Pp. 2749-2766.

9. Kim J.-E., Park W.-S., Jang Y.-I., Kim S.-W., Kim S.W., Nam Y.-H., Kim D.-G., Rokugo K. Mechanical properties of energy efficient concretes made with binary, ternary, and quaternary cementitious blends of fly ash, blast furnace slag, and silica fume. International Journal of Concrete Structures and Materials. 2016. Vol. 10. Pp. 97-108.

10. Alimov L.A., Buldyzhov A.A. Samouplotnyayushchiyesya betony $s$ nanomodifikatorami na osnove tekhnogennykh otkhodov [Selfcompacting concretes with nanomodifiers based on technogenic waste]. Promyshlennoye $i$ grazhdanskoye stroitelstvo. 2014. No. 8. P. 86-88. (rus)

11. Da Silva P.R., De Brito J. Experimental study of the porosity and microstructure of self-compacting concrete (SCC) with binary and ternary mixes of fly ash and limestone filler. Construction and Building Materials. 2015. Vol. 86. Pp. 101-112.

12. Valcuende M., Marco E., Parra C., Serna P. Influence of limestone filler and viscosity-modifying admixture on the shrinkage of self-compacting concrete. Cement and Concrete Research. 2012. Vol. 42. No. 4. Pp. 583-592.

13. Suzdaltsev O.V. Dolgovechnyye arkhitekturnodekorativnyye poroshkovo-aktivirovannyye betony $s$ ispolzovaniyem otkhodov kamnedrobleniya gornykh porod [Durable architectural and decorative powder-activated concrete with waste from quarrying process materials]. Cand. Diss. (Engineering). Penza, 2015. 237 p. (rus)

14. Buldyzhov A.A., Romanov I.V., Voronin V.V., Alimov L.A. Issledovaniye formirovaniya struktury i svoystv mnogokomponentnykh betonov [Study of structure formation and properties of multicomponent concretes]. Nauchnoe obozrenie. 2013. No. 9. Pp. 177-181. (rus)

15. Baldino N., Gabriele D., Lupi F.R., Seta L., Zinno R. Rheological behaviour of fresh cement pastes: Influence of synthetic zeolites, limestone and silica fume. Cement and Concrete Research. 2014. Vol. 63. Pp. 38-45.

16. Petit J.-Y., Wirquin E. Effect of limestone filler content and superplasticizer dosage on rheological parameters of highly flowable mortar under light pressure conditions. Cement and Concrete Research. 2010. Vol. 40. No. 2. Pp. 235-241.

17. Solovyanchik A.R., Korotin V.N., Pulyayev I.S. i dr. Opyt primeneniya samouplotnyayushchikhsya betonnykh smesey pri stroitelstve mostov i tonneley. Mezhdunarodnoye analiticheskoye obozreniye [Experience of application of self-compacting concrete mixtures in construction of bridges and tunnels. International analytical review]. Tsement.
Pp. 123-132.

3. Ramanathan P., Baskar I., Muthupriya P., Venkatasubramani R. Performance of self-compacting concrete containing different mineral admixtures // Journal of Civil Engineering. 2013. Vol. 17. № 2. Pp. 465-472.

4. Muellera F.V., Wallevika O.H., Khayat K.H. Linking solid particle packing of Eco-SCC to material performance /I Cement and Concrete Composites. 2014. Vol. 54. Pp. 117125.

5. Abbas S., Nehdi M.L., Saleem M.A. Ultra-high performance concrete: mechanical performance, durability, sustainability and implementation challenges // International Journal of Concrete Structures and Materials. 2016. Vol. 10. No. 3. Pp. 271-295.

6. Adekunle S., Ahmad S., Maslehuddin M., Al-Gahtani H.J. Properties of SCC prepared using natural pozzolana and industrial wastes as mineral fillers // Cement and Concrete Composites. 2015. Vol. 62. Pp. 125-133.

7. Dinakar P., Sahoo P.K., Sriram G. Effect of metakaolin content on the properties of high strength concrete // International Journal of Concrete Structures and Materials. 2013. Vol. 7. № 3. Pp. 215-223.

8. Da Silva P.R., De Brito J. Durability performance of selfcompacting concrete (SCC) with binary and ternary mixes of fly ash and limestone filler // Materials and Structures. 2016. Vol. 49. № 7. Pp. 2749-2766.

9. Kim J.-E., Park W.-S., Jang Y.-I., Kim S.-W., Kim S. W., Nam Y.-H., Kim D.-G., Rokugo K. Mechanical properties of energy efficient concretes made with binary, ternary, and quaternary cementitious blends of fly ash, blast furnace slag, and silica fume // International Journal of Concrete Structures and Materials. 2016. Vol. 10. Pp. 97-108.

10. Алимов Л.А., Булдыжов А.А. Самоуплотняющиеся бетоны с наномодификаторами на основе техногенных отходов // Промышленное и гражданское строительство. 2014. № 8. C. 86-88.

11. Da Silva P.R., De Brito J. Experimental study of the porosity and microstructure of self-compacting concrete (SCC) with binary and ternary mixes of fly ash and limestone filler // Construction and Building Materials. 2015. Vol. 86. Pp. 101-112.

12. Valcuende M., Marco E., Parra C., Serna P. Influence of limestone filler and viscosity-modifying admixture on the shrinkage of self-compacting concrete // Cement and Concrete Research. 2012. Vol. 42. № 4. Pp. 583-592.

13. Суздальцев О.В. Долговечные архитектурнодекоративные порошково-активированные бетоны с использованием отходов камнедробления горных пород. Диссертация на соискание учёной степени канд. техн. наук. Пенза. 2015. 237 с.

14. Булдыжов А.А., Романов И.В., Воронин В.В., Алимов Л.А. Исследование формирования структуры и свойств многокомпонентных бетонов // Научное обозрение. 2013. № 9. C. 177-181.

15. Baldino N., Gabriele D., Lupi F.R., Seta L., Zinno R. Rheological behaviour of fresh cement pastes: Influence of synthetic zeolites, limestone and silica fume // Cement and Concrete Research. 2014. Vol. 63. Pp. 38-45.

16. Petit J.-Y., Wirquin E. Effect of limestone filler content and superplasticizer dosage on rheological parameters of highly flowable mortar under light pressure conditions // Cement and Concrete Research. 2010. Vol. 40. № 2. Pp. 235-241.

17. Соловьянчик А.Р., Коротин В.Н., Пуляев И.С. Опыт применения самоуплотняющихся бетонных смесей при строительстве мостов и тоннелей. Международное аналитическое обозрение // Цемент. Бетон. Сухие смеси. 2012. № 3(25). С. 8-21.

18. Семенов А.А. Российский рынок извести: тенденции и перспективы развития // Строительные материалы. 2014. № 9. C. 3-7.

Ларсен О.А., Наруть В.В. Самоуплотняющийся бетон с карбонатным наполнителем для объектов транспортной инфраструктуры // Инженерно-строительный журнал. 2016. № 8(68). С. 76-85. 
Beton. Sukhie smesi. 2012. No. 3(25). Pp. 8-21. (rus)

18. Semenov A.A. Rossiyskiy rynok izvesti: tendentsii i perspektivy razvitiya [Russian lime market: trends and prospects]. Stroitelnyye materialy. 2014. No. 9. Pp. 3-7. (rus)

19. Yerofeyev V.T., Bazhenov Yu.M., Balatkhanova E.M., Mitina Ye.A., Yemelyanov D.V., Rodin A.I., Karpushin S.N. Polucheniye i fiziko-mekhanicheskiye svoystva tsementnykh kompozitov s primeneniyem napolniteley $i$ vody zatvoreniya mestorozhdeniy chechenskoy respubliki [The receipt and physico-mechanical properties of cement composites with the use of fillers and mixing water from the Chechen Republic fields]. Vestnik MGSU. 2014. No. 12. Pp. 141-151. (rus)

20. Ghoddousi P., Shirzadi Javid A.A., Sobhani J. Effects of particle packing density on the stability and rheology of selfconsolidating concrete containing mineral admixtures. Construction and Building Materials. 2014. Vol. 53. Pp. 102-109.

21. Craeye B., De Schutter G., Desmet B., Vantomme J., Heirman G., Vandewalle L., Cizer O., Aggoun S., Kadri E.H. Effect of mineral filler type on autogenous shrinkage of selfcompacting concrete. Cement and Concrete Research. 2010. Vol. 40. Pp. 908-913.

22. Nepomuceno M.C.S., Pereira-de-Oliveira L.A., Lopes S.M.R. Methodology for the mix design of self-compacting concrete using different mineral additions in binary blends of powders. Construction and Building Materials. 2014. Vol. 64. Pp. 82-94.

23. Figueiras H., Nunes S., Coutinho J. S., Andrade C. Linking fresh and durability properties of paste to SCC mortar. Cement and Concrete Composites. 2014. Vol. 45. Pp. 209226.

24. Russian Standard GOST 31108-2003. Tsementy obshchestroitelnye. Tekhnicheskiye usloviya [General structural. Portland clinker cements. Specifications]. (rus)

25. Russian Standard GOST 8267-93. Shcheben i graviy iz plotnykh gornykh porod dlya stroitelnykh rabot. Tekhnicheskiye usloviya [Crushed stone and gravel of solid rocks for construction works. Specifications]. (rus)

26. Russian Standard GOST 8269.0-97. Shcheben i graviy iz plotnykh gornykh porod i otkhodov promyshlennogo proizvodstva dlya stroitelnykh rabot. Metody fizikomekhanicheskikh ispytaniy [Mauntainous rock road-metal and gravel, industrial waste products for construction works. Methods of physical and mechanical tests]. (rus)

27. EN 934-2. Admixtures for concrete, mortar and grout. Concrete admixtures. Definitions, requirements, conformity, marking and labelling.

28. Russian Technical conditions 2493-002-13613997-2007. Superplastifikatory dlya betona. SIKA VISCOCRETE [Superplasticizers for concrete. SIKA VISCOCRETE]. (rus)

29. European Guidelines for Self-Compacting Concrete. Specification, Production and Use. EFNARC (European Federation of Producers and Applicators of Specialist Products for Structures). 2005.

30. Okamura H., Ouchi M. Self-Compacting Concrete. Journal of Advanced Concrete Technology. 2003. Vol. 1. No. 1. Pp. 5-15.

31. Nesvetayev G.V., Lopatina Yu.Yu. Proyektirovaniye makrostruktury samouplotnyayushcheysya betonnoy smesi i yeye rastvornoy sostavlyayushchey [The design of macrostructure of self-compacting concrete and its mortar component]. Naukovedeniye. 2015. Vol. 7. No. 5. Pp. 1-14.

32. Russian Standard GOST 10181-2014. Smesi betonnyye. Metody ispytaniy [Concrete mixtures. Methods of testing] (rus)

33. Russian Standard GOST 18105-2010. Betony. Pravila kontrolya i otsenki prochnosti [Concretes. Rules for control and assessment of strength]". (rus)
19. Ерофеев В.Т., Баженов Ю.М., Балатханова Э.М., Митина Е.А., Емельянов Д.В., Родин А.И., Карпушин С.Н. Получение и физико-механические свойства цементных композитов с применением наполнителей и воды затворения месторождений чеченской республики // Вестник МГСУ. 2014. № 12. С. 141-151.

20. Ghoddousi P., Shirzadi Javid A.A., Sobhani J. Effects of particle packing density on the stability and rheology of selfconsolidating concrete containing mineral admixtures /I Construction and Building Materials. 2014. Vol. 53. Pp. 102-109.

21. Craeye B., De Schutter G., Desmet B., Vantomme J., Heirman G., Vandewalle L., Cizer O., Aggoun S., Kadri E.H. Effect of mineral filler type on autogenous shrinkage of selfcompacting concrete // Cement and Concrete Research. 2010. Vol. 40. Pp. 908-913.

22. Nepomuceno M.C.S., Pereira-de-Oliveira L.A., Lopes S.M.R. Methodology for the mix design of self-compacting concrete using different mineral additions in binary blends of powders // Construction and Building Materials. 2014. Vol. 64. Pp. 82-94.

23. Figueiras H., Nunes S., Coutinho J.S., Andrade C. Linking fresh and durability properties of paste to SCC mortar // Cement and Concrete Composites. 2014. Vol. 45. Pp. 209226.

24. ГОСТ 31108-2003 «Цементы общестроительные. Технические условия».

25. ГОСТ 8267-93 «Щебень и гравий из плотных горных пород для строительных работ. Технические условия».

26. ГОСТ 8269.0-97 «Щебень и гравий из плотных горных пород и отходов промышленного производства для строительных работ. Методы фризико-механических испытаний».

27. EN 934-2 «Admixtures for concrete, mortar and grout. Concrete admixtures. Definitions, requirements, conformity, marking and labelling".

28. Технические условия 2493-002-13613997-2007 «Суперпластификаторы для бетона» SIKA VISCOCRETE».

29. European Guidelines for Self-Compacting Concrete. Specification, Production and Use. EFNARC (European Federation of Producers and Applicators of Specialist Products for Structures). 2005.

30. Okamura H., Ouchi M. Self-Compacting Concrete // Journal of Advanced Concrete Technology. 2003. Vol. 1. № 1. Pp. 5-15.

31. Несветаев Г. В., Лопатина Ю. Ю. Проектирование макроструктуры самоуплотняющейся бетонной смеси и её растворной составляющей // Науковедение. 2015. Т. 7. № 5. C. 1-14.

32. ГОСТ 10181-2014 «Смеси бетонные. Методы испытаний».

33. ГОСТ 18105-2010 «Бетоны. Правила контроля и оценки прочности».

34. ГОСТ 7473-2010 «Смеси бетонные. Технические условия».

35. ГОСТ 10180-2012 «Бетоны. Методы определения прочности по контрольным образцам».

36. ГОСТ 10060-2012 «Бетоны. Методы определения морозостойкости».

37. ГОСТ 12730.5-84 «Бетоны. Методы определения водонепроницаемости».

38. Mucteba U., Kemalettin Y. Effect of mineral admixtures on properties of self-compacting concrete // Cement and Concrete Composites. 2011. Vol. 33. Pp. 771-776.

39. Celik K., Jackson M.D., Mancio M., Meral C., Emwas A.-H., Mehta P.K., Monteiro P.J.M. High-volume natural volcanic pozzolan and limestone powder as partial replacements for portland cement in self-compacting and sustainable 
34. Russian standard GOST 7473-2010. Smesi betonnyye. Tekhnicheskiye usloviya [Fresh concrete. Specifications]". (rus)

35. Russian Standard GOST 10180-2012. Betony. Metody opredeleniya prochnosti po kontrolnym obraztsam [Concretes. Methods for strength determination using reference specimens]. (rus)

36. Russian Standard GOST 10060-2012. Betony. Metody opredeleniya morozostoykosti [Concretes. Methods for determination of frost-resistance]. (rus)

37. Russian Standard GOST 12730.5-84. Betony. Metody opredeleniya vodonepronitsayemosti [Concretes. Methods for determination of watertighness]. (rus)

38. Mucteba U., Kemalettin Y. Effect of mineral admixtures on properties of self-compacting concrete. Cement and Concrete Composites. 2011. Vol. 33. Pp. 771-776.

39. Celik K., Jackson M.D., Mancio M., Meral C., Emwas A.-H., Mehta P.K., Monteiro P.J.M. High-volume natural volcanic pozzolan and limestone powder as partial replacements for portland cement in self-compacting and sustainable concrete. Cement and Concrete Composites. 2014. Vol. 45. Pp. 136-147.

Oksana Larsen,

+79031472850; larsen.oksana@mail.ru

Vitaliy Naruts,

+79160774207; insolent88@mail.ru concrete // Cement and Concrete Composites. 2014. Vol. 45. Pp. 136-147.
Оксана Александровна Ларсен, +79031472850; эл. почma: larsen.oksana@mail.ru

Виталий Викторович Наруть,

+79160774207; эл. почma: insolent88@mail.ru

(C) Larsen L.O, Naruts V.V., 2016

Ларсен О.А., Наруть В.В. Самоуплотняющийся бетон с карбонатным наполнителем для объектов транспортной инфраструктуры // Инженерно-строительный журнал. 2016. № 8(68). С. 76-85. 